Reference: Wang, W. and Seifert, R. (2021). "Job stress and employee outcomes: employment practices in a charity", Employee Relations, Accepted to publish on 12-Feb2021, DOI (10.1108/ER-05-2020-0242)

\title{
Job stress and employee outcomes: employment practices in a charity
}

\author{
Abstract (250 words) \\ *Design/methodology/approach (100 words)
}

We collected both quantitative (through a staff survey and administrative records of sick leave in the previous 12 months) and qualitative data (through interviews and focus groups) from one branch of an internationally well-established and UK-based religious charity between 2017 and 2018.

\section{*Purpose (100 words)}

The study intends to examine employee relations with a changing workforce resulting from the business-like transformation in the charity sector. We investigated sector-specific employment practices which can alleviate job stress (as a given and which has been made worse by the transformation). Developed from the intrinsic and extrinsic motivation framework, the findings can inform human resource management practices in its new efficiency-seeking business model.

\section{*Findings (100 words)}

The quantitative results support a strong mediating effect of job satisfaction between job stress and staff sick leave. The negative correlation shown between job stress and job satisfaction is subject to paid staff perception of meaningful work and their level of involvement in decisionmaking, with the latter having a stronger moderating effect. The qualitative data provides further contextualized evidence on the findings.

\section{Practical implications (100)}

It is important for charities to uphold and reflect their charitable mission towards beneficiaries and paid staff during the shift to an efficiency-seeking business model. Charities should involve their new professional workforce in strategic decision-making to better shape a context-based operational model.

\section{*Originality/value (100 words)}

The study examined employee relations in the nonprofit charity sector with a changing workforce during the transition to a more business-oriented model. In particular, we revealed sector-specific factors that can moderate the association between job stress and absenteeism, and thereby contribute to the understanding of HRM practices in the sector.

Keywords: job stress, meaningful work, job satisfaction, absenteeism, involvement in decision-making, religious charities, UK

We appreciate input by Dr. Michael Ogunseyin for an early version of the paper. 


\section{Introduction}

Religious charities are one type of the Not-for-Profit Organizations (NPOs) uniquely defined by their mission. They rely extensively on staff paid under various employment contracts to achieve agreed social goals. There has been a traditionally distinctive set of employee relations in this sector based on the predominance of a shared commitment to the charity's mission. This differentiates it from mainstream instrumental work relations (Akingbola et al., 2020; Ridder and McCandless, 2010). Furthermore, charitable NPOs can prioritize mission over financial performance since they are not obliged to deliver dividends to investors (Cooper et al., 2020). This unique feature of paid employment has tended to attract staff who are motivated by the charity's mission despite poor extrinsic rewards such as low pay and poor employment terms and working conditions (Brown and Yoshioka, 2003; Nickson et al., 2008; Taylor, 2004). However, charitable NPOs, in general, have become more business-like and market-facing, as a result, there has been increasing concern of mission-drift, namely a move away from its mission in pursuing financial success (Bailis et al., 2009; Glennon et al. 2017; Maier et al. 2016). As the chair of the Charity Commissioners stated this sector has seen "aggressive fundraising practices, exploitation of vulnerable people, and single-minded pursuit of organizational growth" (Third Sector, 2018). This may have a fundamental impact on employee relations, which remains under-researched (Akingbola et al. 2020; Maier et al. 2016).

W a successful growth in this sector, a paid and well-qualified workforce has been recruited to deliver the new market-facing social services. There has been a $17 \%$ increase in the paid workforce since 2010 (NCVO, 20190) of whom 51\% have a university degree. This more professional and paid workforce may not be as wedded to the charity's mission as the previously unquestioning loyalty found among the traditional staff. On the other hand, job stress in the sector has increased due to cost-saving measures such as widespread low pay, the use of precarious employment contracts, and the growing dominance of customer-required 
standards in the delivery of social care (Baines et al., 2019; Baluch, 2017; Charlesworth et al. 2015; Cunningham, 2016; Young, 2020). This has led, in recent years, to lower job satisfaction and higher sick leave (CIPD 2017, 2019). We intend to explore employee relations in this sector with the newly configured paid workforce.

We undertook research into one typical religious charity over two years with unique access to substantial quantitative and qualitative data. Findings from this research are intended to contribute to the understanding of contemporary employee relations with a changing workforce. We hope to shed light on the "significant gap in our understanding of the link between employment relations and mission" (Akingbola et al. 2020; p.1046), and answer the call to explore Human Resource Management (HRM) in the nonprofit charity sector (Cooper et al. 2020; Kellner et al., 2017; Maier et al. 2016).

The paper is arranged as follows: a background section to establish the state of contemporary employee relations; a literature review to develop hypotheses; the methodology employed and then findings were presented from both quantitative and qualitative analysis. We conclude with a discussion and implications.

\section{Employment relations in the not-for-profit charity sector in Britain}

Not-for-Profit Organizations (NPOs) are generally known as third-sector organizations, voluntary sector organizations, or non-governmental organizations. Most well-established NPOs originated in religious form. In the UK, for example, more than a quarter of charities, up to 49,881, are faith-based (Church Times, 2016). Unsurprisingly, this sector in and of itself evokes notions of sacrifice traditionally undertaken by followers and volunteers based on the shared values of the 'good Samaritan' (Hackl et al. 2007). Despite the rapid growth of nonreligious NPOs, the general employment relations are still uniquely contextualized in at least two ways: first, NPOs are distinguished by their mission and exist to ultimately achieve some 
social goal as opposed to making profits. Individual employees are often attracted by the mission and values that meet an inherent human need to find meaning in a job (Bowie, 1998; Michaelson et al. 2014) and to attain occupational status and identity from such work (Taylor, 2004). Second, NPOs do not distribute net earnings to their investors, donors, founders and members. This means there is a consensual agreement to back the mission over any financial gains. These unique features enable NPOs to provide goods and services that private industry and governments are unable or unwilling to produce (Brown and Yoshioka, 2003; Cooper et al., 2020). The given mission of any NPO creates the value-fit thus providing an intrinsic motivation for staff to pursue meaningful work despite known poor extrinsic rewards on offer from such paid employment.

Both NPOs' missions and workforce, however, have evolved during the years of the transition to a more private sector business model. With the retreat of state welfare in the 1990s in Britain, NPOs were encouraged to fill the welfare gap through market competition. As a result, they have become more market-facing and business-like (Akingbola et al., 2020; Maier et al., 2016). This sector has seen the emergence of corporate structures (King, 2017; Diaz and Rees, 2020); consumerism (changed attitudes of beneficiaries and funders, Lorimer, 2010; Young, 2020); and commodification (commercialization of NPOs' activities and output, Logan and Wekerle, 2008; Young, 2020). During this process, the belief that NPOs would strive to deliver their mission rather than maximize financial performance (Brown and Yoshioka, 2003) has been put to the test. It is reported that NPOs have reduced the provision of public goods and services to the targeted poor (Bailis et al. 2009), and have shifted towards delivering the objectives of funders rather than their own original mission (Glennon et al., 2017; Diaz and Rees, 2020). It is a cause for concern that a new breed of senior executives who may put"the margin" before "the mission" (Kellner et al., 2017). Our understanding of the impact of business-like transformation on employee relations is limited (Akingbola et al., 2020; Maier et al., 2016), 
although some studies suggest that the job itself has little motivational effect even in faithbased charities (Knapp et al., 2017).

Meanwhile, the workforce has become more professional in order to support bids for competitively funded projects and grants. Statutory grants have declined by $54 \%$ between 2003/04 and 2013/14 (NCVO, 2019). Most large NPOs have recruited more paid staff including an increasing number of professional managers (staff with a business background) and professionally qualified staff in substantive fields (such as medicine, education, social works; Hwang and Powell, 2009; Young, 2020). The increasing pressure from external funding sources to prioritize performance improvement has been internalized into costeffectiveness and efficiency employment practices (Baines, 2009; Cunningham, 2016) and customer-oriented bureaucracy (Young, 2020). This has increased job stress (Baluch, 2017; Charlesworth et al., 2015). The CIPD $(2017,2019)$ reported worse employment evaluations in this sector than in other sectors: for example, lower job satisfaction and higher sick leave. We thus explore the causes of job stress in a changing workforce and seek out the relevant mitigating factors to reduce counter-productive behaviour (such as sick leave).

\section{Job stress and employee outcomes during the transition to new business}

\section{models in religious charities}

Work stress refers to levels of pressure beyond the coping ability of workers (ACAS, 2019; Comish and Swindle, 1994). It is generally attributed to increasing demands of the job (Mauno et al., 2019) leading to work overload, role ambiguity, and work conflicts (Boyd et al., 2009; Sackett and DeVore, 2001). Work in charities is inherently labour intensive both physically and emotionally. This is not only because of the social and emotional interactions that underlie care provision (Baines, 2009; Charlesworth et al., 2015), but also paid staff are close to their 
'clients' and feel intensely the importance of their mission-based employment (Akingbola et al, 2020; Baluch, 2017).

Unsurprisingly, work-based stress has increased as a result of mission-drift due to the substitution of business goals for the quality of service provision. Under the commercialized and contractual nature of the funding environment, there has been increased conflicts between economic costs and charity's social imperative, such as cutting back services for the poor or giving up its mission completely in some cases (Bailis et al. 2009; Glennon et al., 2017). These developments take place without any consultation and agreement from employees. The experience of mission-drift has caused concerns about value-fit, and this in turn has negatively affected meaningful work. Together with the growing prevalence of customer norms -customer choice and control over care provision (Cunningham, 2016; Young, 2020), these shifts away from traditional charity work have caused an identity crisis and decreased work autonomy (Baines, 2009; Young, 2020). This can damage the intrinsic motivation to work in NOPs, and are far more harmful in a faith-based charity.

Secondly, it has increased job insecurity by widely using precarious employment contracts. Most projects are short-term (three years or less) and funded from central and local government, the private sector, and other charities. It has seen an increased use of fixed-term contracts tied to project life, with one-third of the workforce on fixed-term contacts (NCVO, 2019). The greater uncertainty of employment has resulted in job stress, in some cases, employment contracts are being renewed on a weekly basis (Baluch, 2017). The contractual nature of the funding environment has made redundancies increased at an ever-rising rate thus adding to the overall sense of job insecurity (Clark and Wilding, 2011).Furthermore, employment practices have become more cost-sensitive leading to low basic pay made worse through unpaid time (such as traveling to clients' homes) (Baines et al., 2019; Cunningham 2016) and understaffing. The generally stressful working environment dealing with service 
users with social and behavioural problems (Baines and Cunningham, 2011) coupled with job insecurity and workload increases have resulted in job exhaustion (Baines et al., 2014; Charlesworth et al. 2015; Salami, 2010). These features of the new working life for charity paid staff are compounded by the rise of violence towards the staff in care provision (Baines and Cunningham, 2011). The new employment relations in the religious charity under study meant rising tensions between the realities of harsher HRM regimes and the desire to do 'good' and 'meaningful' work. This is the trade-off that allowed charities to pay low wages and maintain poor conditions of service, but with the erosion of trust in the mission comes the destruction of the willingness to work long hard hours for relatively little reward.

The prism of job satisfaction has important attitudinal consequences at work, typically including a high level of organizational commitment and low counter-productive behaviour, such as sick leave and turnover intention (Tett and Meyer, 1993; Knapp et al., 2017; Mahmood et al., 2019; Vincent and Marmo, 2018). Jobs have become unprecedentedly stressful in the charity sector, and this has damaged the renowned devotion of the workforce to the tasks set them. That is to say, job stress leads to low job satisfaction that can mentally and physically exacerbate sick leave. We, therefore, propose that:

Hypothesis 1: Job satisfaction has a mediating effect on the path between job stress and sick leave.

\section{Perceived meaningful work as a moderator between job stress and job satisfaction}

In the context of charities, intrinsic motivation of the job, supporting others in need of help, through deliverable organizational value/mission has been highly emphasised as the stimuli of unseen, intangible, internal beliefs and values propelling an employee to work for them (Christensen and Ebrahim, 2006). Charity ethos is generally considered to meet 'a calling' (Taylor, 2004), such as hope, compassion, and justice. It resonates with the human impulse 
(anthropological and part philosophical) to be engaged in purposeful work of some kind (Bowie, 1998; Michaelson et al., 2014; Williams and Nadin, 2012). This echoes the intrinsic motivation of a job (Cerasoli et al., 2014), and as Robbins and Judge (2013, p135) suggest "the desire of an employee to work on something satisfying, challenging, involving, or exciting". This parallels the recent debate about the need for 'decent jobs' (Gibb and Ishaq, 2020; TUC, 2020). The values or mission of charities were thought to have attracted some self-motivating staff who traditionally accepted lower pay and job stress caused by poorer working conditions of employment (Baluch, 2017; Nickson et al., 2008). That is to say, among those with the same level of perceived job stress, staff who share the mission/value of the organization will feel less stressed. We therefore expect:

Hypothesis 2: The relationship between job stress and job satisfaction is moderated by perceived meaningful work.

Involvement in decision-making as a moderator between job stress and job satisfaction A value-laden consensus as to aims and practices has always formed an important part of charity management but has traditionally been top-down in both the actual chain of command and the prevailing ideologies of want (Seifert, 2019). To meet the drastic fall in the statutory grants, charities have to hire a different range of skilled staff to win contracts and grants from the government, private sector, and national lottery (House of Lords, 2017). These highly skilled professionals, who joined the charity with shared values (Baines, 2009; Kellner et al., 2017), are ideally placed to be involved in shaping the new practices.

The opportunity to have a say in the cause to which one is committed is very important to maintain job interest and satisfaction. This can help staff to manage their expectations and increase their level of engagement (Keating and Heslin, 2015). If staff perceive that they are offered sufficient opportunities to participate in and/or have influence over decisions in pursuit of the mission/value to which they signed up, this gives them a sense of autonomy and 
ownership in decision-made. It can then reduce the level of job stress because higher levels of employee participating in decision-making can attenuate the adverse effect of job stress. We thus suggest that:

Hypothesis 3: Employee participation in decision-making moderates the impact of job stress on job satisfaction.

\section{Methodology}

The primary focus of this research was to examine employee relations in charities during the business-like transformation. We gained access to a typical case organization, one branch of an international leading Christian charity in 2017/2018. Its representativeness is reflected by organizational size (annual income $>£ 10 \mathrm{~m}$ ) and this level of annual income makes it one of the 695 major charities in this sector which have attained successful business expansion over the last three decades (NCVO, 2020). It provides social care services for the homeless. Social services are the fastest growth area in this sector with $37 \%$ of the total workforce (ibid). In addition, it has undertaken business-like operations ( including a mixed funding stream, grant, fees, income from gyms, training services, nursery service as well as fund-raising activities), and the appointment of a HR director since 2014 with a distinct HR department. The majority of paid staff are working on the front line as mentors, coaches, support workers, nursery workers, chefs and cooks, gym instructors, and office workers. There are managers at various levels to fulfill all the business functions, such as finance, enterprises, project managers, HR, and four senior managers. The branch studied has 15 sites with 214 paid employees on the payroll, of whom 64\% are non-Christian and 57\% have a university degree.

We collected quantitative and qualitative data through an online staff survey, interviews with staff ( 3 managers, 6 frontline staff), and two focus groups each with 12 staff representatives, and we examined HR records of staff sick leave. The online survey was sent to 144 employees 
who have an email address and 35 hardcopies were handed out to those who do not have an email address. The overall valid response rate was $79 \%$ (133). The valid survey sample (125) includes permanently contracted (70\%), fixed-term contract (25\%), and relief workers (zerohour contract) (5\%) with 96 women and 29 men. The average age is 39(S.D. =11) ranging between 20 and 68 . The average job tenure of these participants in this branch is 5 years and 7 months, ranging from 1 month to 20 years.

\section{Quantitative analysis}

The dependent variable is the number of days that staff take as authorized sick leave. This was collected from administrative records in the previous 12 months (the length is between 0 and 35 days with an average of 5 days). We excluded those who are on a long-term sick leave after consulting the HR director.

The mediator: job satisfaction. This was used as an indicator of the overall quality of work experience. The scales used throughout are of the usual type (1=strongly disagree through to $5=$ strongly agree). Job satisfaction consists of responses to three survey items: overall, I am satisfied with what I do in my job; I look forward to work when I get up in the morning; and I am enthusiastic about my job alpha $=0.88$; factor loading $>0.71$ ). An exploratory factor analysis indicated these three items to fit one factor (eigenvalue is 2.59 ), reliability analysis also showed these items to be unidimensional (factor loadings>0.56) and internally consistent (Cronbach's alpha $=0.75)$.

The independent variable: Job stress. This was developed from extant literature (Cropanzano et al., 2003). We used three items to capture job stress: I am exhausted in this job because my department is understaffed; in the past 3 months, despite not feeling well enough, I felt pressure from my line manage to come to work; and most of the time, I feel stressed at work. An exploratory factor analysis indicated these three items to fit one factor (eigenvalue 
is 2.79), reliability analysis also showed these items to be unidimensional (factor loadings $>0.66)$ and internally consistent (Cronbach's alpha $=0.72)$.

The moderators: perceived meaningful work and involvement in decision-making. The former is measured by three items: my values match my organization's values; my organization's values and culture provide a good fit with what I value in life; and my work at this charity has a special meaning (it is not just a job). These items were developed from extant literature (Schaufeli et al., 2002; Tett and Meyer, 1993). An exploratory factor analysis indicated these three items to fit one factor (eigenvalue=2.36), reliability analysis also showed these items to be unidimensional (factor loadings>0.65) and internally consistent (Cronbach's alpha $=0.70)$. The latter is measured by three items: at work, my opinions seem to count; I am able to make suggestions to improve the work in my team or department; and I can make decisions that allow me to do my job more effectively. An exploratory factor analysis indicated these three items to fit one factor (eigenvalue $=2.35$ ), reliability analysis also showed these items to be unidimensional (factor loadings $>=0.86$ ) and internally consistent (Cronbach's alpha $=0.83)$.

Table 1 shows the mean and correlations among the main variables. Job stress is negatively and significantly correlated with job satisfaction. Perceived meaningful work and involvement in decision-making are positively and significantly correlated with job satisfaction. High job satisfaction, perceived meaningful work, and high involvement in decision-making are negatively and significantly correlated with the number of sick leave days, respectively.

\section{Table 1 is about here}

\section{Model specification}

We include relevant variables in the investigation of OLS regression on job satisfaction. The moderating effect is tested by including an interactive item. The distribution of the number of days of sick leave taken in the last 12 months is over-dispersed, in particular, $38.6 \%$ of the 
workforce did not take any sick leave, as the conditional variance being 9 which exceeds the conditional mean of 5, a negative binomial regression was considered the appropriate statistical method (UCLA, 2014).

\section{Empirical results and findings}

STATA 13 was employed to examine the mediating effect following the steps outlined by Baron and Kenny (1986) in Table 2. In all analyses, we included job tenure, being a Christian, gender, age, type of contract, and being a manager. Step 1 shows that the total effect between job stress and sick leave is insignificant. As Hayes (2013) and Preacher et al. (2007) have made clear that an insignificant total effect is not the condition for a mediating effect. Step 2 shows a significant and positive correlation between job stress and job satisfaction (the mediator) and step 3 confirms the negative and significant correlation between job satisfaction and sick leave, thus the indirect path pay (job stress->job satisfaction-> sick leave) is established. In step 4, we control for job satisfaction and examine the direct effect between job stress and sick leave that is significant and positive, when we compare the total effect and the direct effect, it indicates a strong mediating effect. That is to say, the significant and detrimental effect of job stress on

sick leave becomes insignificant when staff have a high level of job satisfaction. Thus Hypothesis 1 is supported.

\section{Table 2 is about here}

We further examine the interview evidence on causes of job stress, the theme of uncertainty surrounding project-based funding, and the use of precarious employment contracts. The three main issues mentioned were job insecurity, increased workload, and lack of work-life balance. Project-based contracts caused worries for both staff and managers. As a project manager said, "It's a continuous worry as a manager relying on project funding and needing to secure funding every 1, 2, 3 - 5 years' time. Your focus is needed on delivering the current contract and 
achieving its outcomes along with trying to secure further funding". This is supported by a coach who works on a project “...with the current contract coming to an end I don't feel guaranteed that I could have a job if the organization lost the contract". The stress of job insecurity was even felt by those who are on permanent contracts. One office worker told us, "redundancies have been quite common over the last few years so there is always worry even on a permanent contract". Since staff are recruited according to the project cycle (fixed-term contract), so there is a delay in recruitment after a project starts, and staff tend to leave before the project completion to secure their next job. As a result, permanently contracted staff in the project fill several roles. As a result workload intensified, because as we were told by staff, "unfortunately most departments are understaffed". Lack of work-life balance was also caused by lack of staffing. A support worker (with 3 years' experience) told us, "we often are required to do things outside of office hours, this is the nature of the job it can be difficult to find a work/life balance".

\section{Table 3 is about here}

In order to test the moderated-mediating effect, we first examine the moderating effect of meaningful work and perceived involvement in decision-making on the relationship between job stress and job satisfaction. As shown in steps 1-4 in Table 3. Steps 1 and 3 show that the negative correlations between job stress and job satisfaction are subject to perceived meaningful work, thus hypothesis $\mathbf{2}$ is supported. This shows the importance of upholding the organizational mission. However, there is evidence of mission-drift in the studied charity due to budget pressures on both the treatment of staff and those receiving the much needed help provided. For the former, it was reflected in job insecurity, increased workload, and lack of work-life balance. The latter issue was captured during the service delivery process. As a mentor (two years job tenure) states, "projects are treated as the 'most important' projects, sometimes the pressure to meet targets feels like it becomes more important than helping 
individuals". A coach (with 2 years' experience) told us, "my job entails meeting client targets, and the project can only pay if the paperwork is correct, to this extent, I feel I cannot focus $100 \%$ on my client as I have to think about the time I will need to complete the paperwork and therefore paperwork time is taken up when really I could be seeing more clients and meeting the targets. In some instances, I have completed the paperwork in my own time".

Steps 2 and 4 support a moderating effect of involvement in decision-making, the coefficient is stronger than that of the perceived value-fit. Thus, hypothesis $\mathbf{3}$ is empirically supported. We included these two moderators and its respective interactive items in the regression of sick leave in Steps 5 and 6. It shows none of them has a directly significant impact on sick leave though the effect of job satisfaction has reduced in comparison with Step 4 in Table 3. That is to say that these variables do have an effect on sick leave through its influence on job satisfaction.

Our qualitative analysis shows a general perception that the skilled workers recruited by the organization are under used due to the perceived incompetence of the senior management team. First, senior managers have to be practicing Christians, which limits the talent pool. A theme surrounding the competence of senior managers has emerged in two ways. First, is the strategic position of funding streams. As one professional manager explained, "I feel that the Executive team have lost their vision and are struggling to look ahead in this turbulent business environment because we need to start looking more at sustainability and not being so reliant on funding from central and local government and other funding providers. I do not feel that the current Executive team have the skills to focus in a more business orientated way." Second, it is the lack of professional knowledge of the leaders in certain areas. As an open comment shows, "the executive team are totally ill-prepared for leading the charity forward in positive and proactive ways, albeit there are exceptions within a few departments. We are a charity deeply divided up into small projects and regional areas, and consequently are small fish in a 
very large pond. You need only look at the previous experience of some of them to clearly see how they are in positions in which they have no experience or knowledge; I suggest a simple look at professional online profiles would evidence this". This indicates the constraint of skills and knowledge of senior managers during the business-like transformation, and underlines the importance of involving both professional managers and staff in decisions. Thirdly, there is a general sense of a lack of transparency in decision-making. The top-down communication systems lead to a culture of hearsay and gossip, which in turn leads to staff not feeling motivated. Even the meeting with senior managers, "is more of a conduit to deliver the party line than actually find out what's happening across the service". This was made worse for the "mysterious" decision-making procession. A middle manager (with 4 years) told us, "millionpound decisions were made in the boardroom, where we don't even know who those governors are. I did not see anyone was held accountable when those ventures failed, but colleagues were laid off". Another project manager (with 10 years job tenure) told us, " the project-funding model does not always allow enough time to create a sustainable project as your focus is needed on delivering to the current contract and achieving its outcomes along with trying to secure further funding, why are not we allowed to invest in areas in which we were successful. So we can secure colleagues' jobs". Both professional managers felt the executive team do not appreciate staff knowledge in certain arrears and include them in decisions made, as the project manager put, "I was excluded when it comes to contract reviews as I feel I have valid experience and knowledge that could share but don't feel a part of this process".

\section{Discussion}

We found that an increase in overall job stress among employees in a large faith-based charity was caused by a combination of a cutback in service provision, job insecurity, and lack of influence over decision-making. These consequences have themselves resulted in low job satisfaction and high levels of sick leave. Given the unique employment context in charities, 
we suggest that value-fit and involvement in decision making (having a say in changes) can attenuate the negative impact of job stress on job satisfaction, thereby reducing sick leave. Our findings thus contribute, in at least three ways, to the understanding of employee relations in the under-researched field of HRM in not-for-profit charities.

First, despite the changing workforce, the charity's mission can still be a source of motivation to staff only when the claimed charity ethos is reflected in how staff and service users are treated. Business-like practices that prioritize costs, performance management, and administrative chores as shown in this study have created a gap between workers' expectations of charity employment experience and the reality. As staff mentioned on numerous occasions during interviews, "always remember charity first business second". This is concerning since such mission-drift can damage the intrinsic motivation of the shared values which would motivate staff to deliver additional performance in times of stress (Meyer and Leitner, 2018).

Secondly, this study contributed to the on-going debate of the appropriateness of the use of business-like operations in the not-for-profit charity sector committed to doing 'good' by helping those most in need (Baines 2009; Maier et al. 2016; The Third Sector, 2018). Although the transition to business models has increased efficiency in some aspects, the distinctive nature of not-for-profit from profit-making organizations dictates that this sector should not directly imitate the private sector (Cooper et al. 2020; Lee, 2016). Cost-reduction measures have reduced staff performance and harmed with essential services provided. The use of precarious employment contracts, for example, was deeply resented. Such practices, while having a limited cost-benefit, tend to undermine workgroup strength and reduce commitment forged in pursuit of common value-laden goals.

Thirdly, this study reveals the power distributions in a religious charity that constrains its development. Charities have an unusually high level of sensitive interaction with their external 
worlds - donors, government agencies, media attention, and those in need of support. Extant studies have improved our understanding of the power control of the state and donors through contracts and funding streams (Diaz and Rees, 2020; O'Rourke, 2020). Our study reveals the "concrete" ceiling of a religious requirement to become a senior leader, namely being a practicing Christian. Since senior leaders are found to struggle to make sense of the external changes (King, 2017) and are often constrained by skills and competence as shown in this study, professional staff have much more to offer, but unfortunately, remain undervalued. They have homegrown ideas to generate sustainable income through a diverse funding stream, which can provide job security for themselves and their colleagues. This may hold the key to reducing high levels of staff turnover among the professionally-qualified managers (HarrisHill 2019; Landles-Cobb, et al. 2015).

\section{Managerial implication}

The findings of this study based on detailed empirical research in a typical religious charity suggest that senior managers should uphold their mission and values, and not "bend" their operation due to performance pressures (Bailis et al., 2009; Glennon et al., 2017; Maier et al., 2016). Mission-priority can sustain a charity in at least two ways: firstly, the intrinsic motivation of the mission still matters and can help those who share the mission to overcome job stress. More importantly, when charities practice what they preach by showing compassion to those being served and their own staff, such as with job security and reasonable workload, this can lead to a more satisfied and committed workforce. This can fundamentally differentiate nonprofit employment practices from private business. Secondly, by involving staff in the decision-making process, the charity can use internal expertise to achieve their goals both in terms of funding and innovation, and in service delivery (Hwang and Powell, 2009; O'Rourke, 2020). This is more urgent in an era of welfare cuts, retreat by the government from helping 
the worst off in society, and the historic uncertainty as to the future configuration of the social world of greater inequality.

Our findings are in line with others (Cooper et al, 2020) and suggest the need to move away from management-consultancy-led formulaic employee relations practices, and develop a sector-specific approach rooted in charities' own mission and values. This thus contributes to a new line of enquiry of HRM in nonprofit charities at the organizational level with the changing nature of the workforce (Akingbola et al., 2020; O’Rourke 2020).

\section{Limitation and suggestion for future study}

The study indicates a weakness in the approach to the collection of administrative data from one organization. Despite the merits of such administrative recorded data (Carr et al., 2008; Knapp et al., 2017), the perspective of employees from more organizations can better capture the various aspects of employee relations. With the increasing numbers of skilled paid staff as a result of the business model transformation, it is important to understand the role of staff in the process to shape a context-based operational model that is distinct from private business. Future research might benefit from an interdisciplinary and cross governance, enterprise, and people management. In addition, volunteers are an important resource for this sector. This is a significant gap in our understanding of the link between employment and mission among this group, especially during the efficiency-seeking and professionalization process.

\section{Conclusion}

Employees in non-profit charitable organizations are usually intrinsically motivated by the desire to render services in line with the visions of an organization despite poor extrinsic reward. This meets a human need for meaningfulness of work. This study reveals the importance of leveraging the intrinsic motivator during the efficiency-seeking process in this sector, that is to say, uphold their mission towards service users and staff instead of "bending" 
or "drifting away" from their mission due to the financial pressure. Mission-based employment relations is unique and can provide comparative advantage in the attainment of job satisfaction and to overcome job stress. Our results show that perceived meaningful work and involvement in decision-making can moderate job stress caused by the negative impact on job satisfaction which also has a mediating effect on staff sick leave. We revealed that the ethos/value of the charitable organization only works when it was reflected in the treatment of service users and paid employees, that is to say, charity before business (costs), avoid using precarious employment contracts, and ensure reasonable workload. Involving professional staff in strategic decision-making can further align their aspirations with their tasks, unleash their creativity, and utilize their expertise to meet the charity's fundamental objectives. 
Tables

Table 1 Correlations among main variables.

\begin{tabular}{|c|c|c|c|c|c|c|c|c|c|c|}
\hline & Variables & Mean(S.D.) & 1 & 2 & 3 & 4 & 5 & 6 & 7 & 8 \\
\hline 1 & Days of sick leave & $5.35(9.77)$ & 1 & & & & & & & \\
\hline 2 & Job satisfaction & $3.81(0.78)$ & $-0.27 * * *$ & 1 & & & & & & \\
\hline 3 & Age (years) & $38.99(11.63)$ & -0.00 & -0.03 & 1 & & & & & \\
\hline 4 & Being a male worker & $0.23(0.42)$ & -0.05 & 0.13 & $0.28 * *$ & 1 & & & & \\
\hline 5 & Being a manager & $0.34(0.47)$ & 0.09 & 0.15 & 0.13 & -0.01 & 1 & & & \\
\hline 6 & On a permanent contract & $0.74(0.43)$ & 0.07 & -0.13 & 0.12 & -0.09 & $0.25^{* *}$ & 1 & & \\
\hline 7 & Job Stress & $3.00(0.78)$ & -0.07 & $-0.39 * * *$ & 0.13 & -0.04 & $0.21 * *$ & 0.13 & 1 & \\
\hline 8 & Perceived meaningful work & $3.81(0.76)$ & $-0.21 * *$ & $0.52 * * *$ & 0.15 & $0.24 * * *$ & 0.07 & $-0.21 * *$ & $-0.18 * *$ & 1 \\
\hline 9 & Involvement in decision-making & $4.00(0.89)$ & $-0.22 * *$ & $0.67 * * *$ & -0.10 & 0.06 & 0.09 & 0.02 & $-0.25 * * *$ & $0.31 * * *$ \\
\hline
\end{tabular}

Note: $* \mathrm{p}<0.1 ; * * \mathrm{p}<0.05$; *** $\mathrm{p}<0.00$ 
Table 2 empirical results of the mediating analysis

\begin{tabular}{|c|c|c|c|c|}
\hline Recorded days of sick leave & $\begin{array}{l}\text { Sick leave } \\
\text { (total effect) } \\
\text { Step 1 }\end{array}$ & $\begin{array}{l}\text { Job Satisfaction } \\
\text { Step } 2\end{array}$ & $\begin{array}{l}\text { Sick leave } \\
\text { (direct effect) } \\
\text { Step } 3\end{array}$ & $\begin{array}{l}\text { Sick leave } \\
\text { (direct effect) } \\
\text { Step } 4\end{array}$ \\
\hline Job satisfaction & & & $-0.50 * * *(0.17)$ & $-0.57 * * *(0.18)$ \\
\hline Being a male worker & $-0.01(0.52)$ & $0.19(0.16)$ & $-0.12(0.46)$ & $-0.13(0.46)$ \\
\hline Being a manager & $0.42(0.39)$ & $0.47 * * *(0.15)$ & $0.49(0.37)$ & $0.68 *(0.39)$ \\
\hline /lnalpha & $1.12(0.16)$ & & $1.01(0.16)$ & $0.99(0.16)$ \\
\hline Log likelihood & -278.84 & & -280.14 & -273.67 \\
\hline $\mathrm{R}^{2}$ & & 0.25 & & \\
\hline
\end{tabular}

Note: $* \mathrm{p}<0.1 ; * * \mathrm{p}<0.05 ; * * * \mathrm{p}<0.01$

The result of job satisfaction is based on OLS regression; while the results on sick leave are based on negative-binominal regression due to a large number of observations with 0 day absence. 
Table 3 empirical results of the moderated-mediating analysis

\begin{tabular}{|c|c|c|c|c|c|c|}
\hline Dependent variable & $\begin{array}{l}\text { Job satisfaction } \\
\text { Step } 1\end{array}$ & $\begin{array}{l}\text { Job satisfaction } \\
\text { Step } 2\end{array}$ & $\begin{array}{l}\text { Job satisfaction } \\
\text { Step } 3\end{array}$ & $\begin{array}{l}\text { Job satisfaction } \\
\text { Step } 4\end{array}$ & $\begin{array}{l}\text { Sick leave } \\
\text { Step } 5\end{array}$ & $\begin{array}{l}\text { Sick leave } \\
\text { Step } 6\end{array}$ \\
\hline Job satisfaction & & & & & $-0.52 * *(0.27)$ & $0.49 *(0.22)$ \\
\hline Job tenure & $-0.05(0.04)$ & $-0.05(0.04)$ & $-0.04(0.04)$ & $-0.04(0.03)$ & $-0.03(0.04)$ & $-0.04(0.03)$ \\
\hline Age(years) & $-0.00(0.00)$ & $0.00(0.00)$ & $-0.00(0.00)$ & $0.00(0.00)$ & $0.00(0.02)$ & $-0.00(0.48)$ \\
\hline Being a Christian & $0.20(0.39)$ & $0.19(0.36)$ & $0.19(0.36)$ & $0.18(0.36)$ & $0.18(0.36)$ & $0.27(0.40)$ \\
\hline Being a male worker & $0.04(0.15)$ & $0.02(0.12)$ & $0.02(0.13)$ & $0.12(0.13)$ & $-0.11(0.45)$ & $-0.24(0.42)$ \\
\hline Being a manager & $0.37 * * *(0.13)$ & $0.28 * * *(0.11)$ & $0.37 * * *(0.11)$ & $0.36 * * *(0.11)$ & $0.64(0.39)$ & $0.65(0.42)$ \\
\hline Permanent contracted & $-0.08(0.14)$ & $-0.16(0.12)$ & $-0.07(0.12)$ & $-0.29 * *(0.12)$ & $0.26(0.42)$ & $0.28(0.45)$ \\
\hline Job stress & $-0.34 * * *(0.07)$ & $-0.23 * * *(0.06)$ & $-0.37(0.43)$ & $-0.32(0.26)$ & $0.39 * *(0.16)$ & $-0.67(1.01)$ \\
\hline Perceived meaningful work & $0.45 * * *(0.08)$ & $0.29 * * *(0.07)$ & $1.01 * * *(0.34)$ & & $-0.67(0.45)$ & \\
\hline $\begin{array}{l}\text { Involvement in decision- } \\
\text { making }\end{array}$ & & $0.45^{* * *}(0.06)$ & & $0.99 * * *(0.22)$ & & $-0.88(0.71)$ \\
\hline $\begin{array}{l}\text { Job stress *perceived } \\
\text { meaningful work }\end{array}$ & & & $-0.18 *(0.11)$ & & $0.23(0.32)$ & \\
\hline $\begin{array}{l}\text { job stress *Involvement in } \\
\text { decision-making }\end{array}$ & & & & $-0.15 * *(0.06)$ & & $0.22(0.20)$ \\
\hline /lnalpha & & & & & $0.96(0.17)$ & $0.89(0.16)$ \\
\hline Log likelihood & & & & & -272.58 & -272.58 \\
\hline $\mathrm{R}^{2}$ & 0.41 & 0.62 & 0.42 & 0.58 & & \\
\hline
\end{tabular}

Note: $* \mathrm{p}<0.1 ; * * \mathrm{p}<0.05 ; * * * \mathrm{p}<0.01$ 
Figures

Figure 1: Empirical results

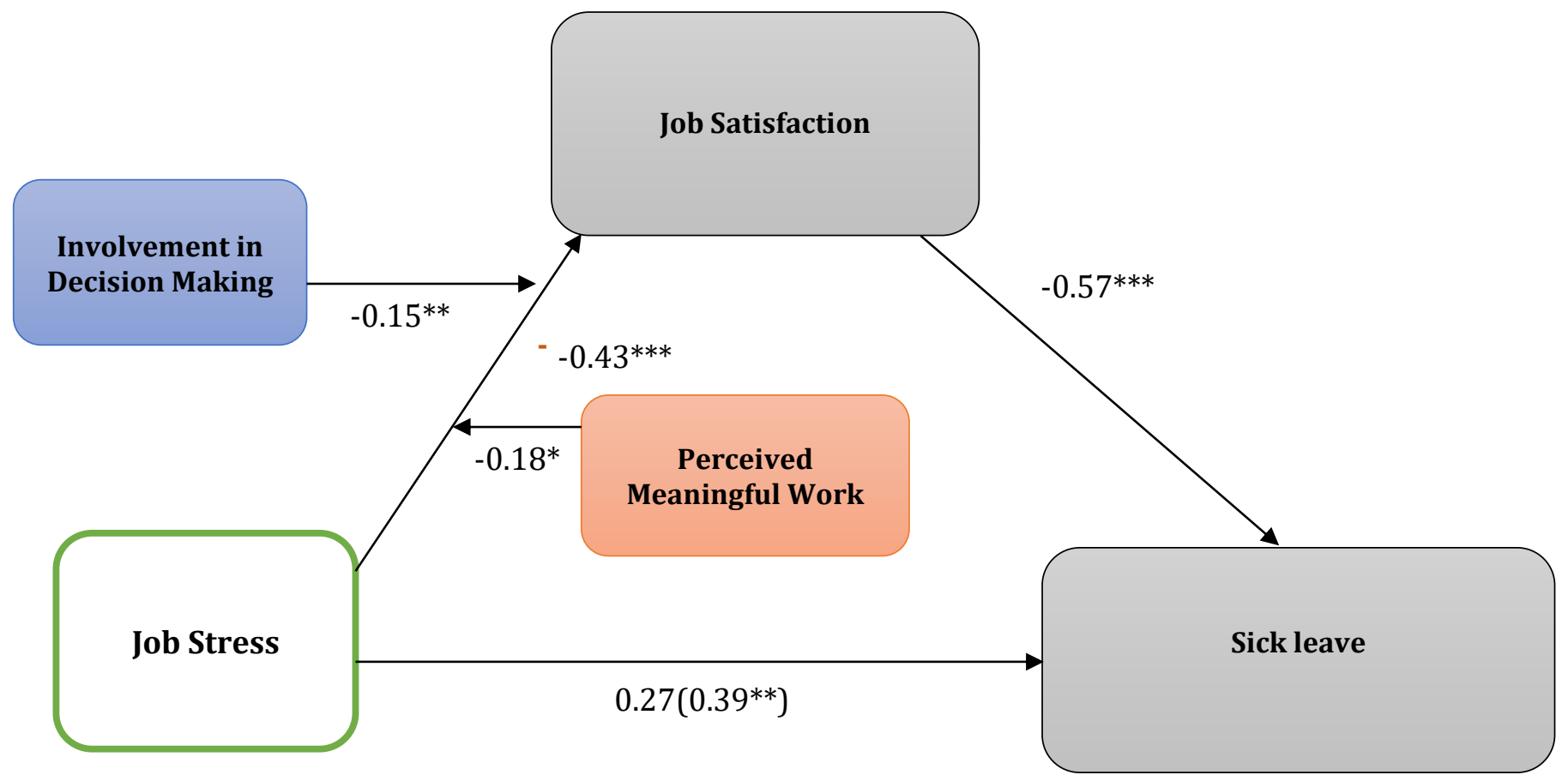




\section{References}

ACAS (2019) Stress and Anxiety at work: personal or cultural? ACAS, London.

Akingbola, K., Baluch, A., Brunt, C. and Cunningham, I. (2020), "Editorial", Employee Relations, Vol. 42 No. 5, pp. 1045-1054.

Bailis, R., Cowan, A., Berrueta, V., and Masera, O. (2009), "Arresting the Killer in the Kitchen: The Promises and Pitfalls of Commercializing Improved Cookstoves”, World Development, Vol.37 No.10, pp.1694-1705.

Baines, D. (2009), “'If We Don't Get Back to Where We Were Before': working in the restructured non-profit social services". British Journal of Social Work, Vol.40 No.3, pp.928945.

Baines, D., and Cunningham, I. (2011), "White knuckle care work': violence, gender and new public management in the voluntary sector", Work, employment and society, Vol.25 No.4, pp.760-776.

Baines, D., Charlesworth, S., Turner, D., and O’Neill, L. (2014), "Lean social care and worker identity: The role of outcomes, supervision and mission", Critical Social Policy, Vol.34 No.4, pp.433-453.

Baines, D., Kent, P., and Kent, S. (2019), “'Off My Own Back': Precarity on the Frontlines of Care Work", Work, Employment and Society, Vol.33 No.5, pp.877-887.

Baluch, A. M. (2017), "Employee perceptions of HRM and well-being in nonprofit organizations: unpacking the unintended", The International Journal of Human Resource Management, Vol.28 No.14, pp.1912-1937.

Baron, R.M. , and Kenny, D.A. (1986), "The moderator-mediator variable distinction in social psychological research: Conceptual, strategic, and statistical considerations”, Journal of Personality and Social Psychology, Vol. 51 No.6, pp.1173-1182.

Boyd, N.G., Lewin, J.E. and Sager, J.K. (2009), “A model of stress and coping and their influence on individual and organizational outcomes", Journal of Vocational Behavior, Vol. 75 No.2, pp.197-211.

Brown, W. A., and Yoshioka, C. F. (2003), Mission attachment and satisfaction as factors in employee retention, Nonprofit Management and Leadership, Vol.14 No.1, pp.5-18.

Bowie, N.E., (1998). "A Kantian theory of meaningful work". Journal of Business Ethics, 17(9/10): 1083-1092.

Carr, J. C., Boyar, S. L., and Gregory, B. T. (2008), "The moderating effect of work-family centrality on work-family conflict, organizational attitudes, and turnover behavior". Journal of Management, Vol.34 No.2, pp.244-262 
Cerasoli, C. P., Nicklin, J. M., and Ford, M. T. (2014), "Intrinsic motivation and extrinsic incentives jointly predict performance: A 40-year meta-analysis". Psychological bulletin, Vol.140 No.4, pp.980-1008.

Christensen, R., and Ebrahim, A., (2006), "How Does Accountability Affect Mission? The Case of a Nonprofit Serving Immigrants and Refugees", Nonprofit Management and Leadership, Vol. 17 No. 2, pp. 195-209.

Charlesworth, S., Baines, D., and Cunningham, I. (2015), "If I had a family, there is no way that I could afford to work here': Juggling paid and unpaid care work in social services", Gender, Work and Organization, Vol.22 No.6, pp. 596-613.

Church Times, 29 April 2016, A quarter of UK Charities are faith-based, Available at https://www.churchtimes.co.uk/articles/2016/29-april/news/uk/a-quarter-of-uk-charities-arefaith-based

CIPD. (2017). Employee Outlook Spring 2017.

CIPD. (2019). Employee Outlook Spring 2019

Clark, J. and Wilding, K., (2011), 3 trends in voluntary sector employment. In Voluntary Organizations and Public Service Delivery,pp. 37-53, New York: Routledge.

Comish, R., and Swindle, B. (1994), "Managing stress in the workplace", National Public Accountant, Vol.39 No.9, pp.24-28.

Cooper, E.A., Phelps, A.D. and Rogers, S.E. (2020), "Research in nonprofit human resource management from 2015 to 2018: Trends, insights, and opportunities", Employee Relations, Vol. 42 No. 5, pp. 1055-1100.

Cropanzano, R., Rupp, D. E., and Byrne, Z. S. (2003), “The relationship of emotional exhaustion to work attitudes, job performance, and organizational citizenship behaviors', Journal of Applied psychology, Vol.88No.1, pp.160-169.

Cunningham, I. (2016), "Non-profits and the 'hollowed out'state: the transformation of working conditions through personalizing social care services during an era of austerity', Work, employment and society, Vol.30 No.4, PP.649-668.

Diaz, D.A. and Rees, C.J. (2020), "Checks and balances? Leadership configurations and governance practices of NGOs in Chile", Employee Relations, Vol.42 No.5, pp.1159-1177.

Gibb, S. and Ishaq, M. (2020), "Decent work: what matters most and who can make a difference?", Employee Relations, Vol. 42 No. 4, pp. 845-861

Glennon, R., Hannibal, C., and Meehan, J. (2017). "The impact of a changing financial climate on a UK local charitable sector: voices from the front line". Public Money \&Management, Vo.37 No.3, pp.197-204 
HarrisHill (Charity recruitment specialists), (2019), "Don't go! Tacking talent retention in the charity sector, available at https://www.harrishill.co.uk/blog/2019/03/talent-retention

Hackl, F., Halla, M. and Pruckner, G.J., (2007). "Volunteering and income-the fallacy of the good samaritan?", Kyklos, Vol.60 No.1, pp.77-104.

Hayes, A. F. 2013. Introduction to mediation, moderation, and conditional process analysis: A regression-based approach. New York, NY: Guilford.

House of Lords Report, (2017). "Stronger charities for a stronger society, available at https://publications.parliament.uk/pa/ld201617/ldselect/ldchar/133/133.pdf

Hwang, H. and Powell, W. W. (2009), "The Rationalization of Charity: The Influences of Professionalism in the Nonprofit Sector", Administrative Science Quarterly, Vol.54 No.2, pp.268298.

Kellner, A., Townsend, K., and Wilkinson, A. (2017), "The mission or the margin?'A highperformance work system in a non-profit organization". The International Journal of Human Resource Management, Vol.28 No.14, pp.1938-1959.

Knapp, J. R., Smith, B. R., and Sprinkle, T. A. (2017), “Is it the job or the support? Examining structural and relational predictors of job satisfaction and turnover intention for nonprofit employees", Nonprofit and Voluntary Sector Quarterly, Vol.46 No.3, pp. 652-671

Keating, L. A., and Heslin, P. A. (2015),“'The potential role of mindsets in unleashing employee engagement'. Human Resource Management Review, Vol.25 No.4, pp. 329-341.

King, D. (2017). "Becoming business-like: governing the nonprofit professional", Nonprofit and Voluntary Sector Quarterly, Vol.46No.2, pp.241-260.

Landles-Cobb, L., Kramer,K., and Milway K.S. (2015). "The Nonprofit Leadership Development Deficit. Stanford Social Innovation Review. 22 October

Lee, Y.J., (2016), "Comparison of job satisfaction between nonprofit and public employees”, Nonprofit and Voluntary Sector Quarterly, Vol.45 No.2, pp.295-313.

Logan, S. and Wekerle, G.R., (2008), "Neoliberalizing environmental governance? Land trusts, private conservation and nature on the Oak Ridges Moraine", Geoforum, Vol. 39 No.6, pp.2097-2108.

Lorimer, J. (2010), 'International conservation 'volunteering' and the geographies of global environmental citizenship", Political geography, Vol. 29 No.6, pp.311-322.

Mahmood, A., Akhtar, M.N., Talat, U., Shuai, C. and Hyatt, J.C. (2019), "Specific HR practices and employee commitment: the mediating role of job satisfaction", Employee Relations, Vol. 41 No. 3, pp. 420-435. 
Maier, F., Meyer, M. and Steinbereithner, M., (2016), "Nonprofit organizations becoming business-like: A systematic review". Nonprofit and Voluntary Sector Quarterly, Vol. 45No.1, pp.64-86.

Mauno, S., Kubicek, B., Minkkinen, J. and Korunka, C. (2019), "Antecedents of intensified job demands: evidence from Austria", Employee Relations, Vol. 41 No. 4, pp. 694-707

Meyer, M. and Leitner, J. (2018), "Slack and innovation: the role of human resources in nonprofits", Nonprofit Management and Leadership, Vol. 29, pp. 181-201.

Michaelson, C., Pratt, M.G., Grant, A.M. and Dunn, C.P. (2014). Meaningful work: Connecting business ethics and organization studies. Journal of Business Ethics, 121(1):77-90.

NCVO, UK civil society almanac (2019), Workforce, Accessed on 30 Nov 2020. Available at: https://data.ncvo.org.uk/a/almanac17/workforce-4/

Nickson, D., Warhurst, C., Dutton, E., and Hurrell, S. (2008), “A job to believe in:

Recruitment in the Scottish voluntary sector", Human Resource Management Journal, Vol.18 No.1, pp.20-35.

O'Rourke, P.P. (2020), "How NPM-inspired-change impacted work and HRM in the Irish voluntary sector in an era of austerity", Employee Relations, Vol. 42 No. 5, pp. 1101-1116.

Preacher, K. J., Rucker, D. D., \& Hayes, A. F. (2007), "Addressing moderated mediation hypotheses: Theory, methods, and prescriptions". Multivariate behavioral research, Vol.42 No.1,pp. 185-227.

Ridder, H.-G. and McCandless, A. (2010), "Influences on the architecture of human resource management in nonprofit organizations: an analytical framework", Nonprofit and Voluntary Sector Quarterly, Vol. 39 No. 1, pp. 124-141.

Robbins, S.P., and Judge, T. (2013), Essentials of organizational behavior. Upper Saddle River, New Jersey: Pearson Education, pp.134-138

Sackett, P. R., and DeVore, C. J. (2001),Counterproductive behaviors at work. In N. Anderson, D. S. Ones, H. K. Sinangil, \& C. Viswesvaran (Eds.), Handbook of industrial, work, and organizational psychology (Vol. 1, pp. 145-151). Thousand Oaks, CA: Sage

Salami, S.O., (2010), "Job stress and counterproductive work behaviour: Negative affectivity as a moderator". The Social Sciences, Vol.5 No.6, pp.486-492.

Schaufeli, W. B., Salanova, M., González-Romá, V., and Bakker, A. B. (2002). “The measurement of engagement and burnout: A two sample confirmatory factor analytic approach". Journal of Happiness studies, Vol.3 No.1, pp.71-92.

Seifert, R., (2019). 'Marxism'. In Elgar Introduction to Theories of Human Resources and Employment Relations (pp.16-33). Edward Elgar Publishing. 
Taylor, R.F., (2004), "Extending conceptual boundaries: work, voluntary work and employment". Work, employment and society, Vol.18 No.1, pp.29-49.

Tett, R. P., and Meyer, J. P. (1993), “Job satisfaction, organizational commitment, turnover intention, and turnover: path analyses based on meta-analytic findings". Personnel psychology, 46(2), 259-293.

Trade Union Congress (2020), “Ten steps for a Spending Review to create decent jobs". Available at https://www.tuc.org.uk/blogs/ten-steps-spending-review-create-decent-jobs

UCLA (2014), “ Negative Binomial Regression: STATA Data Analysis Examples”. Available at https://stats.idre.ucla.edu/stata/dae/negative-binomial-regression/

Vincent, D. and Marmo, S. (2018), "Commitment to social justice and its influence on job satisfaction and retention of nonprofit middle managers ", Human Service Organizations:

Management, Leadership and Governance, Vol. 42 No. 5, pp. 457-473.

Williams, C.C. and Nadin, S., (2012), "Work beyond employment: representations of informal economic activities". Work, employment and society, Vol.26 No.2, pp.1-10.

Young, D.,(2020), " 'I was never trained to do any of that'-personalisation and the impact of the "customer" on employment relations in voluntary sector social care". Employee Relations, Vol.42 No.5, pp.1117-1133. 